\title{
The phytochemical properties of a new citrus hybrid (Citrus hystrix $\times$ Citrus microcarpa)
}

\author{
Abdul-Halim Yahya, Gun-Hean Chong*, Chin-Ping Tan \\ Department of Food Technology, Faculty of Food Science and Technology, Putra Malaysia University, \\ 43400 UPM Serdang, Selangor Darul Ehsan, Malaysia
}

*Corresponding author, e-mail: gunhean@upm.edu.my

Received 10 Apr 2013

Accepted 19 Jan 2014

\begin{abstract}
The Merdeka lime is a new citrus hybrid with strong resistance against pests and disease. This work aims to provide information about the total phenolic content (TPC), total flavonoid (TF) content and antioxidant potential of the leaves, peel and pulp of this new hybrid along with those of its parent plants (Citrus hystrix and C. microcarpa). The TPC and TF contents were determined based on a colorimetric method, while antioxidant levels were determined by the 2,2-diphenyl-1-picrylhydrazyl (DPPH) and the ferric-reducing antioxidant power (FRAP) techniques. The results revealed that Merdeka lime contained the highest TPC $(4600 \pm 140 \mu \mathrm{g}$ gallic acid equivalents per gram of dry weight) and DPPH value $(4260 \pm 30 \mu \mathrm{g}$ Trolox equivalents per gram of dry weight) in the leaves and the highest $\mathrm{TF}(16400 \pm 300 \mu \mathrm{g}$ quercetin equivalents per gram dry weight) and FRAP value (13430 $\pm 60 \mu \mathrm{g}$ ascorbic acid equivalent per gram of dry weight) in the peel. The antioxidant activities of Merdeka lime were similar to the parent plants.
\end{abstract}

KEYWORDS: Merdeka lime, makrut lime, antioxidant, phenolic compounds, flavonoid compounds

\section{INTRODUCTION}

An antioxidant is a substance that is able to prevent an excessive amount of free radicals in biological systems ${ }^{1}$. It also plays an important role in food preservation by reducing lipid peroxidation preventing quality deterioration ${ }^{2,3}$. Natural antioxidants have therefore become a new focus in nutritional studies as the consumers believe that natural products are healthier and safer ${ }^{1,4}$. Numerous studies have proven that the phytochemical compounds produced in the plant are one of the best sources of natural antioxidant, such as those found in the citrus ${ }^{5-7}$.

A new citrus hybrid $(C$. hystrix $\times C$. microcarpa), known as the Merdeka lime in Malaysia, was introduced in 2010. The Merdeka lime has larger fruits (Fig. 1) and leaves than its parent plants, and it has been cultivated without the use of pesticides. The increased resistance to pests indicates that this hybrid might produce novel secondary metabolites or have undergone changes in metabolite composition. There is an urgent need for information about this hybrid to enable more detailed studies. The aim of this study was therefore to determine the total phenolic content (TPC), total flavonoid (TF) content and the antioxidant activity of this new citrus hybrid (C. hystrix $\times C$. microcarpa) relative to its parent cultivars.

\section{MATERIALS AND METHODS}

\section{Plant materials}

Three lime varieties, namely $C$. hystrix, $C$. microcarpa, and the Merdeka lime $(C$. hystrix $\times C$. microcarpa), were used in this study. The leaves of all three varieties and the fruit of the Merdeka lime were harvested from a Laverson Biotech farm in Batang Kali, Hulu Selangor, Malaysia. C. hystrix and C. microcarpa fruits were obtained from local markets in Serdang, Selangor, Malaysia. All leaf samples were dried in the open air in the laboratory until the moisture content reached less than $10 \%$ (wet basis). All fruit samples were manually cleaned and separated into peel and pulp samples, with the seeds removed. The peel and pulp were dried with a vacuum freezedryer (Labconco FreeZone, Kansas City, MO, USA) at $-40{ }^{\circ} \mathrm{C}, 10 \mathrm{~Pa}$ until the moisture content was less than $10 \%$ (wet basis). All dried samples were ground into powder and stored at $-10^{\circ} \mathrm{C}$.

\section{Chemicals and reagents}

Folin-Ciocalteu's reagent, gallic acid, $\mathrm{Na}_{2} \mathrm{CO}_{3}$, $\mathrm{NaNO}_{2}, \mathrm{AlCl}_{3}, \mathrm{NaOH}$, and 6-hydroxy-2,5,7,8-tetramethylchroman-2-carboxylic acid (Trolox) were purchased from Sigma-Aldrich Chemical Co. (St. Louis, 


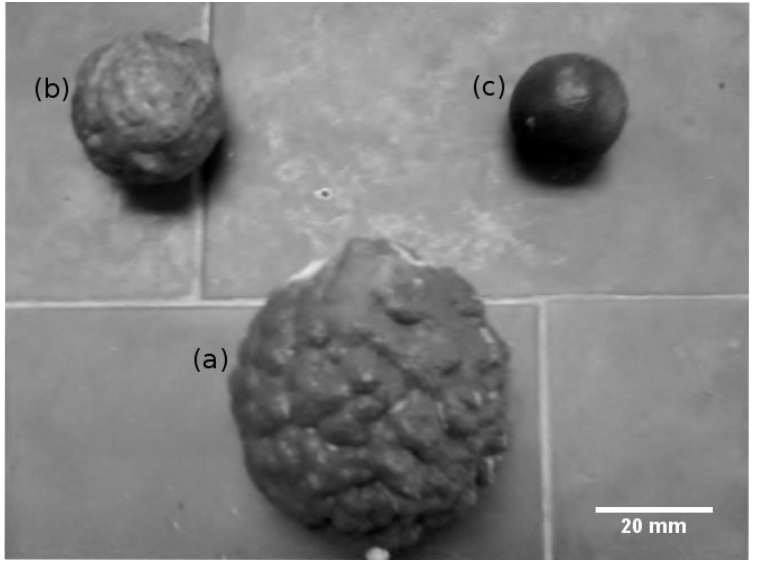

Fig. 1 (a) Merdeka lime crossbred from (b) Citrus hystrix and (c) C. microcarpa.

MO, USA); 2,2-diphenyl-1-picrylhydrazyl (DPPH) was purchased from Merck (Darmstadt, Germany).

\section{Extraction of phytochemicals}

The leaves, peel and pulp (5 g) of C. hystrix, C. microcarpa and the Merdeka lime were extracted with $80 \%$ methanol (v/v) overnight at $25^{\circ} \mathrm{C}$ on an orbital shaker (Hotech Instrument Corp., 903, Taiwan). The mixtures were then centrifuged for 5 min at $2380 \mathrm{~g}$ (Beckman Coulter, Avanti J-25.15, USA). The supernatant was filtered through a Büchner funnel and Whatman no. 1 filter and collected. The crude extracts were obtained by evaporating the extracts to dryness under reduced pressure using a vacuum rotary evaporator (Stuart, RE300, UK) at a temperature below $40^{\circ} \mathrm{C}$. The extracts were re-suspended in $50 \mathrm{ml}$ of $80 \%$ methanol (v/v) and used to measure phytochemical contents and to determine total antioxidant activity. The extraction was done in triplicate.

\section{Determination of total phenolic content (TPC)}

The total phenolic content of the lime extracts was measured by using the Folin-Ciocalteu colorimetric method as described by Almey et $\mathrm{al}^{4}$. Briefly, $100 \mu \mathrm{l}$ of extract sample was transferred into a test tube and mixed with $0.75 \mathrm{ml}$ Folin-Ciocalteu reagent (diluted 10 -fold with distilled water). The mixture was allowed to stand for $5 \mathrm{~min}$ at $25^{\circ} \mathrm{C}$. Then $0.75 \mathrm{ml}$ of $6 \%$ (w/v) $\mathrm{Na}_{2} \mathrm{CO}_{3}$ was added and mixed gently. The mixture was allowed to stand for $60 \mathrm{~min}$, after which its absorbance was read at $725 \mathrm{~nm}$ (Thermo Electron Corporation, Genesys 20, California, USA). The results were expressed as $\mu \mathrm{g}$ gallic acid equivalents (GAE) per gram of dry weight, calculated using a standard calibration curve prepared with gallic acid $(0-100 \mu \mathrm{g} / \mathrm{ml})$. The analysis was done in triplicate.

\section{Determination of total flavonoid content}

The total flavonoid content of the samples was measured using the colorimetric method adapted from Jia et $\mathrm{al}^{8}$, with modifications as described by Zhang et $\mathrm{al}^{9}$. Briefly, $0.25 \mathrm{ml}$ of extract sample was added into a test tube containing $0.75 \mathrm{ml}$ of distilled water. Then, $0.15 \mathrm{ml}$ of $\mathrm{NaNO}_{2}$ (5\%) was added to the test tube, and the solution was mixed gently. The mixture was allowed to stand for $5 \mathrm{~min}$, and then $0.3 \mathrm{ml}$ of $\mathrm{AlCl}_{3}(10 \%)$ was added; after an additional $5 \mathrm{~min}$, $1 \mathrm{ml}$ of $\mathrm{NaOH}(1 \mathrm{M})$ was added. The solution was mixed well, and the absorbance was read at $510 \mathrm{~nm}$. Quercetin concentrations ranging of $0.04-0.20 \mathrm{mg} / \mathrm{ml}$ were used to prepare the standard calibration curve. The results were expressed as $\mu$ g quercetin equivalents per gram of dry weight. The analysis was done in triplicate.

\section{DPPH free radical-scavenging activity}

The DPPH free radical scavenging activity method was adapted from Ismail et al ${ }^{10}$. Briefly, a $0.2 \mathrm{mM}$ DPPH methanolic solution was freshly prepared immediately prior to the analysis. The analytical samples were prepared at $0.5 \mathrm{mg} / \mathrm{ml}$, and $50 \mu \mathrm{l}$ of each analytical sample was mixed with $195 \mu \mathrm{l}$ of the $0.2 \mathrm{mM}$ DPPH methanolic solution in a 96-well microplate. The plate was gently swirled and incubated for $60 \mathrm{~min}$ in the dark. All the extract samples were read at $515 \mathrm{~nm}$ in a 96-well ELISA microplate reader (BioTek, BIOTEL ELx800, Winoosk, USA). Trolox was used as the standard, and a calibration curve in the range of $20-100 \mu \mathrm{g} / \mathrm{ml}$ was prepared. The analysis was done in triplicate. The DPPH scavenging activity was determined by $\left(\left(A_{\mathrm{e}}-A_{\mathrm{n}}\right) / A_{\mathrm{s}}\right)$, where $A_{\mathrm{e}}, A_{\mathrm{n}}$, and $A_{\mathrm{s}}$ are the absorbance of the extract, absorbance of the negative control, and standard absorbance of the negative control, respectively.

\section{Ferric reducing antioxidant power (FRAP) assay}

The FRAP assay was performed according to procedure described by Zhang et $\mathrm{al}^{9}$. FRAP reagent was freshly prepared and it consisted of $10 \mathrm{ml}$ ferric chloride $(20 \mathrm{mM}), 10 \mathrm{ml}$ of $10 \mathrm{mM} \mathrm{Fe}(\mathrm{III})-2,4,6-$ Tri(2-pyridyl)-s-triazine (TPTZ) in $40 \mathrm{mM} \mathrm{HCl}$ and $100 \mathrm{ml}$ of $0.25 \mathrm{M}$ sodium acetate buffer (pH 3.6). The FRAP reagent was warmed at $37^{\circ} \mathrm{C}$. Then $0.5 \mathrm{ml}$ analytical sample was added to $1.5 \mathrm{ml}$ of FRAP reagent and gently mixed. The absorbance was read at $593 \mathrm{~nm}$ after $10 \mathrm{~min}$ incubation at $37^{\circ} \mathrm{C}$. Calibration curve of ascorbic acid was used as standard at range of 


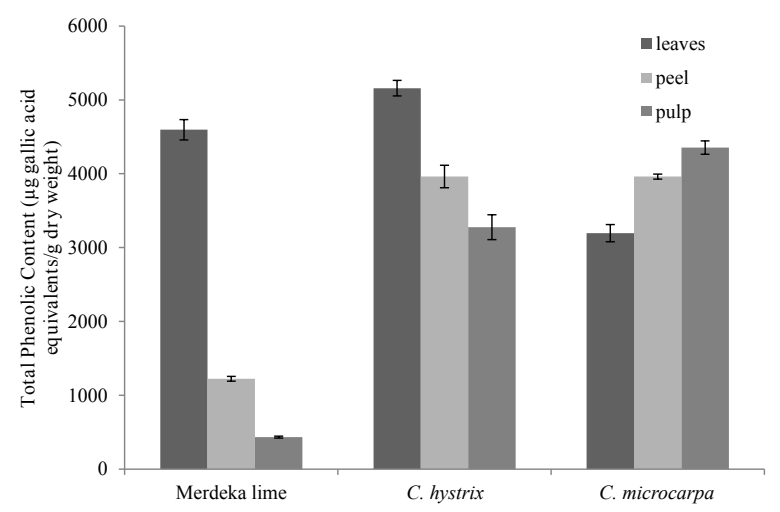

Fig. 2 Total phenolic content in Merdeka lime, C. hystrix and C. microcarpa.

4-30 $\mu \mathrm{g} / \mathrm{ml}$ and results were expressed as $\mu \mathrm{g}$ ascorbic acid per gram of dry weight. The analysis was done in triplicate.

\section{Statistical analysis}

The results are expressed as the means of the replicates \pm standard deviations. Significant differences at the $95 \%$ confidence level were calculated based on Duncan's multiple range tests using IBM SPSS Statistic 19.0 (IBM SPSS Inc., USA).

\section{RESULTS AND DISCUSSION}

The result of univariate ANOVA showed that the parts of hybrid (peel, pulp, and leaves) and of parent plants presented significantly different TPC $(p<0.05)$. As shown in Fig. 2, in Merdeka lime the highest TPC was found in the leaves $(4595.8 \mu \mathrm{g}$ GAE per gram of dry weight) and the amount was comparable to that of C. hystrix (5158.3 $\mu \mathrm{g}$ GAE per gram of dry weight). The TPC in Merdeka lime was also comparable to white grapefruit (4201 $\mu \mathrm{g}$ GAE per gram of dry weight) and Jaffa sweetie grapefruits (4065 $\mu \mathrm{g} \mathrm{GAE}$ per gram of dry weight ${ }^{11}$.

The TF contents were found significantly different in the hybrid and the parents plant $(p<0.05)$. In the Merdeka lime (Fig. 3), the peel contained the highest TF (16395 $\mu \mathrm{g}$ quercetin equivalents per gram of dry weight) and the pulp had the lowest content of TF (1257 $\mu$ g quercetin equivalents per gram of dry weight). The pulp of Mauritian Citrus was also found had the lowest content of $\mathrm{TF}^{12}$.

The hybrid and the parent plants reacted differently in DPPH analysis $(p<0.05)$, except the leaves of Merdeka lime compared to the leaves of $C$. hystrix. In Merdeka lime (Fig. 4), the leaves presented the highest radical scavenging activity (4259.5 $\mu$ g Trolox equivalents per gram of dry weight) followed by the

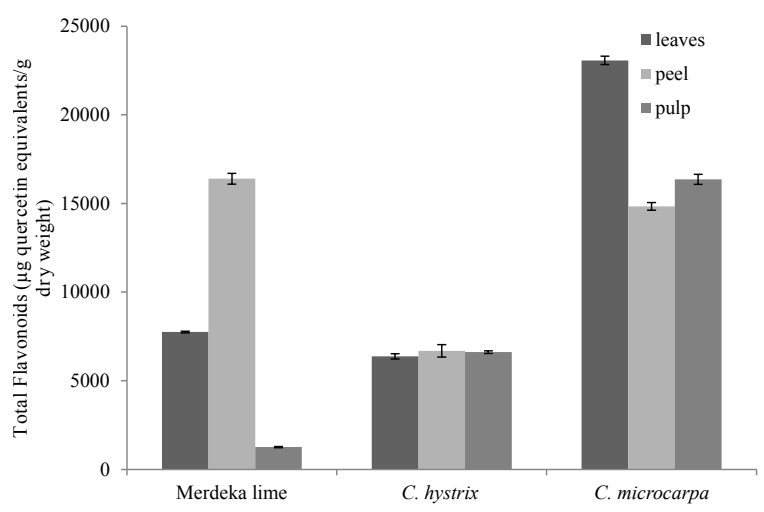

Fig. 3 Total flavonoid content in Merdeka lime, C. hystrix and C. microcarpa.

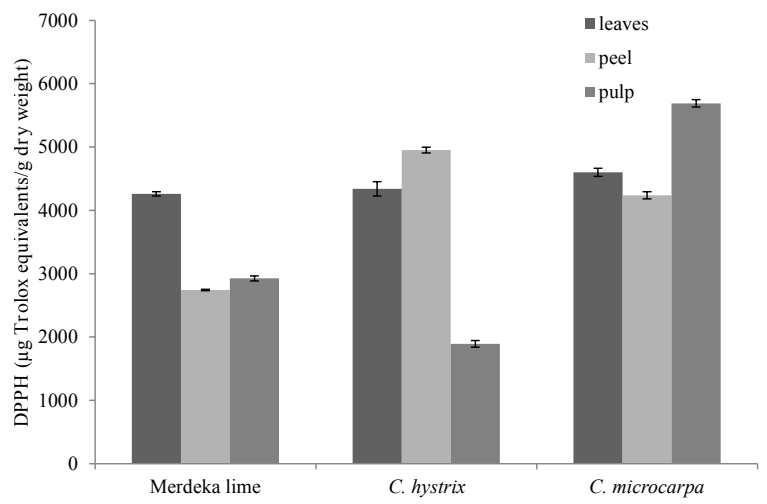

Fig. 4 DPPH radical scavenging activity of Merdeka lime, C. hystrix and C. microcarpa.

pulp $(2925.0 \mu \mathrm{g}$ Trolox equivalents per gram of dry weight) and the peel (2741.1 $\mu \mathrm{g}$ Trolox equivalents per gram of dry weight).

The result of FRAP showed that there was no significant difference $(p>0.05)$ in the antioxidant activities between the parts of Merdeka lime and part of the parent plants except the pulp of hybrid. In Merdeka lime (Fig. 5), the peel showed the highest antioxidant activity (13 $427.0 \mu \mathrm{g}$ ascorbic acid equivalent per gram of dry weight) and the pulp presented the lowest one (2510.0 $\mu$ g ascorbic acid equivalent per gram of dry weight). Merdeka lime (leaves and peel) however had a good antioxidant activity as compared with some jujube cultivars, such as hamidazao (3724.9 $\mu \mathrm{g}$ ascorbic acid equivalent per gram of dry weight) and dongzao (9823.1 $\mu \mathrm{g}$ ascorbic acid equivalent per gram of dry weight $)^{9}$.

\section{CONCLUSIONS}

The antioxidant properties of the Merdeka lime (leaves, peel, and pulp) were investigated in this 


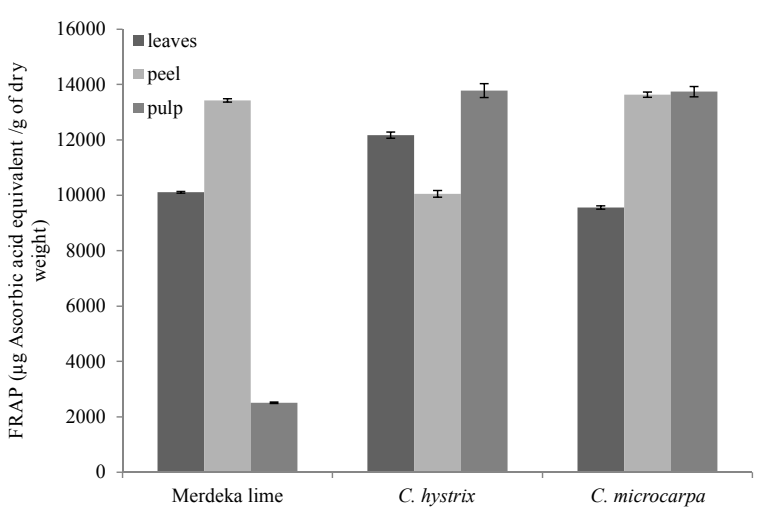

Fig. 5 Ferric-reducing antioxidant activity (FRAP) of Merdeka lime, C. hystrix and C. microcarpa.

study. Of the tissues analysed, the leaves contained the highest TPC, and the peel contained the highest TF. The Merdeka lime also presented antioxidant activity comparable to that of other fruits. As a new hybrid, however, the Merdeka lime should be studied further.

Acknowledgements: This study received financial support from RUGS grants (Vot no. 9300360). The authors wish to acknowledge Mr Devandran from LeVarson Biotech Sdn. Bhd. for supplying the leaves and the fruits of Merdeka lime and other samples.

\section{REFERENCES}

1. Conde-Hernández LA, Guerrero-Beltrán JA (2014) Total phenolics and antioxidant activity of Piper auritum and Porophyllum ruderale. Food Chem 142, 455-60.

2. Moure A, Cruz JM, Franco D, Domínguez JM, Sineiro J, Domínguez H, Núñez MJ, Parajó JC (2001) Natural antioxidants from residual sources. Food Chem 72, 145-71.

3. Delgado Adámez J, Gamero Samino E, Valdés Sánchez E, González-Gómez D (2012) In vitro estimation of the antibacterial activity and antioxidant capacity of aqueous extracts from grape-seeds (Vitis vinifera L.). Food Contr 24, 136-41.

4. Almey AAA, Khan CAJ, Zahir IS, Suleiman KM, Aisyah MR, Rahim KK (2010) Total phenolic content and primary antioxidant activity of methanolic and ethanolic extracts of aromatic plants' leaves. Int Food Res $J$ 17, 1077-84.

5. Mäkynen K, Jitsaardkul S, Tachasamran P, Sakai N, Puranachoti S, Nirojsinlapachai N, Chattapat V, Caengprasath N, Ngamukote S, Adisakwattana S (2013) Cultivar variations in antioxidant and antihyperlipidemic properties of pomelo pulp (Citrus grandis [L.] Osbeck) in Thailand. Food Chem 139, 735-43.

6. Park HY, Choi HD, Eom H, Choi I (2013) Enzymatic modification enhances the protective activity of citrus flavonoids against alcohol-induced liver disease. Food Chem 139, 231-40.

7. Pająk P, Socha R, Gałkowska D, Rożnowski J, Fortuna $T$ (2014) Phenolic profile and antioxidant activity in selected seeds and sprouts. Food Chem 143, 300-6.

8. Zhishen J, Mengcheng T, Jianming W (1999) The determination of flavonoid contents in mulberry and their scavenging effects on superoxide radicals. Food Chem 64, 555-9.

9. Zhang H, Jiang L, Ye S, Ye Y, Ren F (2010) Systematic Evaluation of Antioxidant capacities of the ethanolic extract of different tissues of jujube (Ziziphus Jujuba Mill.) from China. Food Chem Toxicol 48, 1461-5.

10. Ismail HI, Chan KW, Mariod AA, Ismail M (2010) Phenolic content and antioxidant activity of cantaloupe (Cucumis melo) methanolic extracts. Food Chem 119, 643-7.

11. Gorinstein S, Cvikrová M, Machackova I, Haruenkit R, Park YS, Jung ST, Yamamoto K, Martinez Ayala AL et al (2004) Characterization of antioxidant compounds in Jaffa sweeties and white grapefruits. Food Chem 84, 503-10.

12. Ramful D, Tarnus E, Rondeau P, Robert Da Silva C, Bahorun T, Bourdon E (2010) Citrus fruit extracts reduce advanced glycation end products (AGEs)- and $\mathrm{H}_{2} \mathrm{O}_{2}$-induced oxidative stress in human adipocytes. J Agr Food Chem 58, 11119-29. 